\title{
Hizmetkâr Liderlik Davranışının Örgütsel Özdeşleşme ve İşgören Performansı Üzerine Etkisi: Restoran Çalışanları Üzerinde Bir İnceleme \\ (The Effect of Perceived Servant Leadership Behaviour on the Organizational Identification and Performance Of Employees: A Research on Restaurant Employees)
}

\section{Hasan CINNİOĞLU iD a}

a İskenderun Teknik Üniversitesi, Turizm Fakültesi, Turizm ve Otel İșletmeciliği Bölümü, Hatay, Türkiye. hasan.cinnioglu@iste.edu.tr.

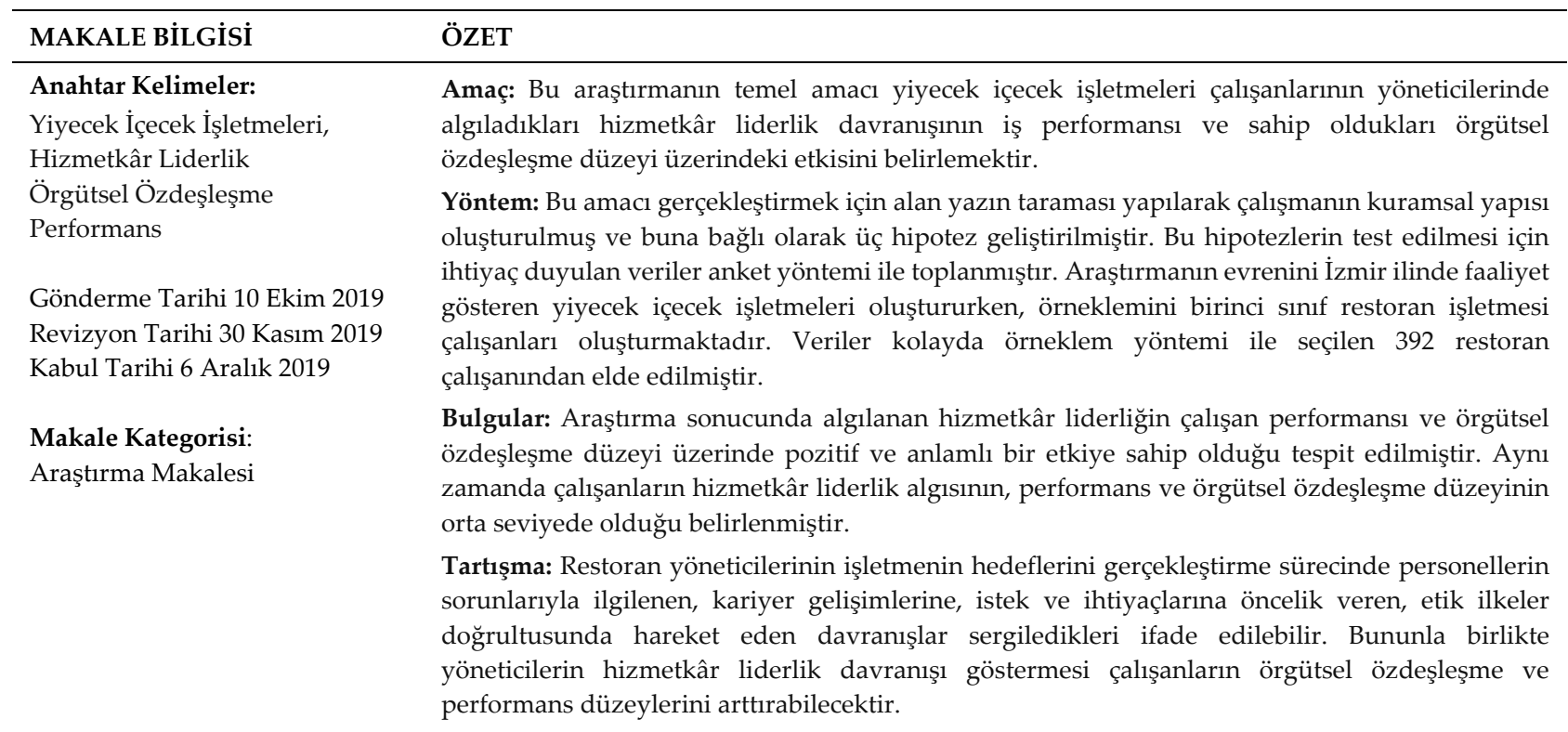

\begin{tabular}{|c|c|}
\hline ARTICLE INFO & ABSTRACT \\
\hline Keywords: & cpose: The main purpose of this study is to determine the effect of perceived servant leadership \\
\hline $\begin{array}{l}\text { Food and beverage } \\
\text { businesses }\end{array}$ & $\begin{array}{l}\text { behaviour of restaurant employees on the organizational identification and performance of } \\
\text { employees. }\end{array}$ \\
\hline Servant Leadership & Design/methodology/approach: In order to realize the purpose of the research, the theoretical \\
\hline Organizational Identification & structure of the study was formed via literature research and depending on this structure, three \\
\hline Performance & $\begin{array}{l}\text { hypotheses were developed. The data needed to test these hypotheses were collected by } \\
\text { questionnaire method. The population of the research consists of food and beverage }\end{array}$ \\
\hline Received 10 October 2019 & establishments operating in İzmir Province, and the sample is composed of first class restaurant \\
\hline Revised 30 November 2019 & employees. The data were obtained from 392 restaurant employees selected by sampling method. \\
\hline Accepted 6 December 2019 & $\begin{array}{l}\text { Findings: As a result of the research, it was determined that perceived servant leadership has a } \\
\text { positive and significant effect on employee performance and organizational identification level. }\end{array}$ \\
\hline \multirow[t]{2}{*}{$\begin{array}{l}\text { Article Classification: } \\
\text { Research Article }\end{array}$} & $\begin{array}{l}\text { At the same time, it was determined that employees' perceptions of servant leadership and their } \\
\text { level of performance and organizational identification were moderate. }\end{array}$ \\
\hline & $\begin{array}{l}\text { Discussion: İt can be stated that restaurant managers exhibit behaviors that deal with the } \\
\text { problems of the personnel, give priority to their career development, wishes and needs and act in } \\
\text { line with ethical principles in the process of achieving the objectives of the business. If the } \\
\text { managers exhibit servant leadership behavior may increase the organizational identification and } \\
\text { performance levels of the employees. }\end{array}$ \\
\hline
\end{tabular}




\section{Giriş}

Yiyecek içecek işletmeleri emeğin yoğun bir şekilde kullanıldığı, misafirlerin üretim sürecinde yer aldığı, çalışma saatlerinin esnek olduğu bir sektördür. Zorlu çalışma şartlarına rağmen yiyecek içecek işletmeleri de diğer işletmeler gibi amaç ve hedeflerine başarılı bir şekilde ulaşmak ister. Bu noktada yiyecek içecek işletmelerinde çalışan personelin göstereceği performans ya da işletmeyle özdeşleşmesi belirlenen hedeflerin başarısına önemli katkılar sağlayabilecektir. Çalışanların performans ya da özdeşleşme düzeyleri ise birçok faktörden etkilenebilmektedir. Bu faktörlerden bir tanesi de yöneticilerin benimsedikleri liderlik davranışlarıdır. İşletmenin amaçlarına ulaşma sürecinde yöneticilerin göstermiş olduğu liderlik tarzı çalışanların performans düzeylerini ya da örgütsel özdeşleşmelerini doğrudan etkileyebilecektir. Alan yazında çok farklı liderlik türleri olmasına rağmen hangi liderlik türünün bu değişkenler üzerinde olumlu etki yaratacağının belirlenmesi önem arz etmektedir. Bu nedenle modern liderlik türlerinden biri olan hizmetkar liderlik algısının çalışanların performansına ve örgütsel özdeşleşme düzeyine ne yönde katkılar yapacağının belirlenmesi, bu çalışmanın temel amacını oluşturmaktadır. Bu amaçla çalışmada öncelikle literatür taraması yapılarak değişkenlere yönelik kuramsal çerçeve çizilmiş ve anket yöntemi ile İzmir ilinde faaliyet gösteren birinci sınıf restoran çalışanlarından veriler elde edilmiştir.

\section{Kuramsal Çerçeve}

Greenleaf tarafından yapılan çalışmalar neticesinde literatüre kazandırılan hizmetkâr liderlik kavramı (Singfiel, 2018: 66), bir liderin her şeyden önce hizmetkâr olmasını ifade etmektedir (Greenleaf 1977: 2). Greenleaf, hizmetkâr liderlik tanımını literatüre kazandırmasından sonra hizmetkâr liderliğin özelliklerini belirlemeye yönelik birçok çalışma yapılmıştır. Bu özelliklerden bazıları şu şekildedir: hizmetkârlık, vizyon oluşturma, dürüst olma ve etik davranma, personel güçlendirme, fedakarlık, duygusal iyileştirme, empati, takipçilerin gelişimine ve başarısına yardım etmedir (Wong ve Page 2003: 3; Patterson 2003: 2; Winston 2003: 6; Liden vd. 2008: 162: Baldonado, 2017: 53). Hizmetkârlık felsefesi ile liderin rollerini birleştirip tek bir rol haline getiren hizmetkâr liderlik, yöneten konumundaki kişilerin rollerinde ciddi değişiklikleri beraberinde getiren yeni nesil bir liderlik modelidir (Yıldırım, 2019: 2244). Diğer liderlik modellerinin birçoğu öncelikle misyona odaklanıp daha sonra bu misyonu gerçekleştirmek için takipçilerin güçlendirmesine odaklanırken, hizmetkâr lider öncelikle bireylerin kabiliyetlerini geliştirmeye odaklanır, misyonun başarısına odaklanmak daha sonraki süreçte yer alır (Gandolfi ve Stone, 2018: 265). Hizmetkâr lider aynı zamanda, takipçileri ilişkisel, etik, duygusal ve manevi gibi çeşitli boyutlarda geliştirme yeteneğine sahiptir (Eva vd. 2019: 111). Yöneticilerin hizmetkâr liderler gibi takipçilerinin ihtiyaçlarına odaklanması işletme açısından birçok olumlu sonuca neden olacaktır (Baldonado, 2017: 56; Lee vd. 2019). İşletme yöneticilerinin hizmetkâr liderlik davranışı göstermesi, çalışan yaratıcılı̆̆ını (Yıldırım, 2019: 2244), örgütsel vatandaşlığı (Amir 2019: 1; Shoukat vd. 2019: 67), işe adanmışlığı (Cinnioğlu ve Saçlı 2019: 1776), örgütsel kültür ve çalışanların performansını (Muhtasom vd. 2017: 71), örgütsel kimlik ve işe olan ilgiliyi (Akbari vd. 2014: 41) pozitif yönde; işten ayrılma niyetini ise negatif yönde (Cinnioğlu vd. 2018: 109) etkileyebilmektedir.

Özdeşleşme kavramı, alan yazında ilk olarak politik bilimlerde çalışma yapan Harrold Lasswell (1935) tarafından "psikolojik, sosyolojik ve söz bilimle ilgili bir kavram" olarak kullanılmıştır (Tokgöz ve Seymen 2013: 63). Özdeşleşme, örgüt içerisinde faaliyetlerini sürdüren kişilerin örgütle kendisini tanımlayabilmesi ve örgüte ait olduğunu hissedebilmesidir (Kerse ve Karabey 2017: 379). Örgütsel özdeşleşme ile ilgili ilk model, March ve Simon tarafından 1958'de geliştirmiş olmasına rağmen özdeşleşmenin günümüzdeki anlamıyla kullanımı 1970'lerden sonra yapılan araştırmalarda yer almıştır (Çakınberk vd. 2011: 92). Örgütsel özdeşleşme, sosyal kimlik teorisini örgütsel bağlamda uygulayan Mael ve Ashforth tarafından yeniden kavramsallaştırılmıştır (Tsuchiya 2017: 2). Mael ve Ashforth’a göre (1992: 103), örgütsel özdeşleşme, “örgütün başarılı ya da başarısız olduğu durumlarda örgüte aidiyetin ve birlik olmanın algılanmasıdır". Özdeşleşme kişinin bir örgütü algılamasından ziyade kendini algılaması temeline dayanır. Başka bir ifade ile örgütle özdeşleşmek benlik algısını geliştirmek ya da korumak için bir yoldur (Bhattacharya ve Elsbach 2002: 28). Aynı zamanda örgütsel özdeşleşme, örgüt içerisindeki bireyin, örgütün temel örgütsel kimlik özellikleri ile kendini bütünleştirme düzeyidir (Eker 2015: 119). İşletmelerde örgütsel özdeşleşmenin gerçekleşebilmesi için güçlü bir örgüt kültürüne, etkili yönetime, iyi iletişim kanallarına, psikolojik sözleşmenin oluşmasına ve ortak değer paylaşıma ihtiyaç vardır (Hamzagic 2018: 2). Aslında örgütsel özdeşleşmenin oluşabilmesi için genel olarak ihtiyaç duyulan unsurlara bakıldığında, işletmede bu unsurları sağlayabilecek kişilerin liderler olduğu ortaya çıkmaktadır. Başka bir ifade ile örgüt kültürünü, etkili yönetimi ya da iyi iletişim kanallarını 
oluşturacak olan işletme liderleridir. İsgörenlerin yöneticilerinde algıladıkları hizmetkâr liderlik davranışı örgütsel özdeşleşme düzeyini etkileyebilecek temel liderlik türlerinden biridir (Çelik 2018: 765). Alanyazın incelendiğinde liderlik algısının çalışanların örgütsel özdeşleşme düzeylerini pozitif yönde etkilediğini ortaya koyan çalışmaların olduğu görülmektedir (Zhang vd. 2012; Akbari vd. 2014; Ateş 2015; Thomas vd. 2015; Chughtai 2016; Narcıkara ve Zehir 2017; Çelik 2018; Nart vd. 2018; Tian 2018; Zorlu vd. 2019). İlgili yazın neticesinde araştırmada aşağıdaki hipotez geliştirilmiştir:

H1: Algılanan hizmetkâr liderlik davranışı örgütsel özdeşleşmeyi pozitif yönde etkilemektedir.

Performans, işletme içerisinde görev yapan kişi ya da grupların belirlenen amaca ulaşabilmek bakımından nasıl bir sonuç elde ettiklerini açıklayan bir kavramdır (Yılmaz ve Karahan 2010: 147). Başka bir ifade ile performans, çalışanların uzmanlık ve kabiliyetlerine dayalı olarak gerçekleştirilen faaliyetlerin sonuçlarıdır (Dahkoul 2018: 12). Kişi ya da grup performansı, örgütün amaçları doğrultusunda kişinin ya da grubun kendileri için belirlenen hedeflere ve standartlara ne ölçüde ulaşabildiğinin göstergesi olarak ifade edilebilir (Çöl 2008: 39). İşgörenlerin yüksek performansa sahip olması işletmelerin başarısı açısından oldukça önemlidir (Uygur 2007: 74). Çünkü bünyelerinde yüksek performanslı çalışanların olduğu örgütlerde, istenilen amaç ve hedeflere ulaşmak daha kolay olabilmektedir (Ali vd. 2016: 301). Çalışanların performansını yükseltmede ise yöneticilerin liderlik davranışları önem arz eden bir konudur. Çünkü liderler çalışanlara rehber olmakta, onları etkileyerek motivasyon ve performanslarının artmasını sağlamaktadır (Tekin 2018: 344). Bu bağlamda modern liderlik tarzlarından biri olan hizmetkâr liderlik çalışanların performansına pozitif yönde katkı sağlayabilecektir. Alan yazında bu değişkenlere yönelik çok az sayıda araştırma olmasına rağmen, araştırma sonuçları hizmetkâr liderliğin çalışanların performansını olumlu yönde etkilediğini ortaya koymuştur (Hussain ve Ali 2012; Chiniara ve Bentein 2016; Taşlıyan vd. 2016; Muhtasom vd. 2017; Wang vd. 2017). Bu nedenle çalışmada aşağıdaki hipotez geliştirilmiştir:

H2: Algılanan hizmetkâr liderlik davranışı çalışanların performansını pozitif yönde etkilemektedir.

Çalışmada geliştirilen hipotezlere bağlı olarak oluşturulan araştırma modeli aşağıdaki gibidir:



Şekil 1: Araştırmanın modeli

\section{Yöntem}

$\mathrm{Bu}$ çalışmanın temel amacı birinci sınıf restoran işletmelerindeki çalışanların yöneticilerinde algıladıkları hizmetkâr liderlik davranışının örgütsel özdeşleşme ve iş performansı düzeylerine etki edip etmediğinin belirlenmesidir. Bu temel amacın yanında çalışanların hizmetkâr liderlik algılarını, örgütsel özdeşleşme ve performans düzeylerini ortaya koymak çalışmanın alt amaçlarındandır. Araştırma kapsamında ele alınan değişkenlerin bir arada fazla incelenmemiş ve özellikle bu değişkenler yiyecek içecek işletmeleri açısından çok fazla ele alınmamıştır. Bu nedenle araştırma sonuçları hem değişkenlerin işletmeler açısından kuramsal yapıda belirtilen öneminden dolayı hem de alan yazındaki bu boşlukları doldurmasından dolayı önem arz etmektedir.

Araştırmanın evrenini İzmir ilinde faaliyet gösteren yiyecek içecek işletmeleri, örneklemini ise bölgedeki turizm işletme belgeli birinci sınıf restoran çalışanları oluşturmaktadır. İzmir ilinde 2019 tarihi itibariyle turizm işletme belgeli toplam 63 adet yeme içme tesisi bulunmaktadır. Bu işletmelerden 34 tanesi birinci sınıf restoran işletmesidir (Web 1). Ancak bu tesislerde çalışan sayıları hakkına net bilgiler elde edilememiştir. Bu 
nedenle evreninin net olarak bilinmediği durumlarda kullanılan örneklem büyüklügü formülü \% 95 güven düzeyinde hesaplanmış ve örneklem büyüklüğü 384 kişi olarak belirlenmiştir (Ural ve Kılıç, 2013: 45). Bu kişilerin belirlenmesinde ise basit tesadüfi örneklem yöntemi kullanılmıştır. Örneklem grubundaki katılımcıların \% 67,3'ü erkek, \% 51,3'üü bekar, \% 39,5',i 26-35 yaş aralığında, \%48,2'si lise mezunu, \%42,1', 2100 TL ve altı maaş aralığındadır.

Araştırmada veri toplama aracı olarak anket tekniğinden yararlanılmıştır. Anket Ağustos-Eylül 2019 tarihleri arasında yüz yüze yapılmıştır. İki bölümden oluşan anketin ilk bölümü değişkenlere yönelik beşli likert şeklinde derecelendirilmiş (1 Kesinlikle Katılmıyorum-5 Kesinlikle Katılıyorum) ifadelerden, ikinci bölümü ise demografik sorulardan oluşmaktadır. Toplamda 410 anket dağıtılmış olup, eksik ve hatalı anketler çıkarıldıktan sonra geçerli 392 anket elde edilmiştir. Araştırmada kullanılan ölçekler şu şekildedir:

Hizmetkâr Liderlik Ölçeği: Araştırmada çalışanların hizmetkâr liderlik algısını ölçmek için Liden vd. (2015) geliştirmiş olduğu tek boyut ve yedi ifadeden oluşan, Türkçe'ye Kılıç ve Aydın (2016) tarafından çevrilen ve birçok çalışmada geçerliliği, güvenirliliği sağlanmış (Chiniara ve Bentein 2016; Chughtai 2016; Brohi vd 2018; Cinnioğlu ve Saçlı 2019) ölçek kullanılmıştır. Ölçekteki bazı ifadeler şu şekildedir: "Şahsi bir problemim olduğunda yöneticimden yardım isteyebilirim", "Yöneticim kariyer gelişimime öncelik verir".

Örgütsel Özdeşleşme Ölçeği: Mael ve Ashforth (1992) tarafından geliştirilen, tek boyuttan ve altı ifadeden oluşan ölçek kullanılmıştır. Ölçeğin geçerlilik ve güvenirlilik çalışmaları daha önceki birçok çalışmada (Lipponen vd. 2008; Jones ve Volpe 2010; Turunç ve Çelik 2010; Aliyev ve Işık 2014; Fettahlıŏlu ve Koca 2015; Eker 2015) sağlanmıştır. Ölçekteki ifadelerden bazıları: "İşletmenin başarısı benim başarımdır", İşletmemden bahsederken onlar değil biz diye konuşurum" şeklindedir.

İşgören Performansı Ölçeği: Kirkman ve Rosen ile Sigler ve Pearson tarafından geliştirilen ve Türkçe'ye Çöl (2008) tarafından çevrilen tek boyut ve dört ifadeden oluşan ölçek kullanılmıştır. Ölçeğin geçerlilik ve güvenirliği birçok araştırmada (Yılmaz ve Karahan 2010; Ayan 2015; Tekingündüz vd. 2016; Tekin 2018) yapılmıştır. Ölçekteki ifadelerden bazıları şu şekildedir; "İş hedeflerime fazlasıyla ulaşırım", "Görevimi zamaninda tamamlarım".

\section{Araştırmanın Bulguları}

Araştırmada kullanılan ölçeklerin yapı geçerliliğini ortaya koymak amacıyla öncelikle açıklayıcı faktör analizi yapılmıştır. Ölçeklerin faktör analizine uygunluğu Kaiser Meyer- Olkin (,60'den büyük olması) ve Barlett küresellik testi sonuçlarına göre (,000 olması) değerlendirilmiştir. Faktör analizler neticesinde ortaya çıkan ölçek boyutlarının güvenirliliğini ölçmek için de Cronbach's Alfa katsayıları hesaplanmıştır. Tablo 1'de verilen hizmetkâr liderlik ölçeğine ilişkin faktör analizi ve güvenirlilik bulgularına bakıldığında ölçeğin tek boyut altında toplandığı ve bu boyutun toplam varyansın \%58,793'ünü açıkladığ görülmektedir (KMO=,823; $\mathrm{p}=0,000)$. Aynı zamanda ölçeğin de güvenilir olduğu belirlenmiştir (Cronbach's Alfa= ,816).

Tablo 1. Hizmetkar Liderlik Ölçeğine İlişkin Faktör Analizi ve Güvenilirlik Bulguları

\begin{tabular}{|l|l|}
\hline Maddeler & Faktör Yükü \\
\hline Yöneticim topluluğa geri vermenin (yardım etmenin) önemini vurgular. &, 916 \\
\hline $\begin{array}{l}\text { Yöneticim zor sorunları en iyi hissettiğim yolla idare etmem (çözmem) için bana serbestlik } \\
\text { verir. }\end{array}$ &, 861 \\
\hline Şahsi bir problemim olduğunda yöneticimden yardım isteyebilirim. &, 843 \\
\hline Yöneticim eğer bir şeyler yanlış gidiyorsa bunu söyleyebilir. &, 814 \\
\hline Yöneticim kariyer gelişimime öncelik verir. &, 611 \\
\hline Yöneticim başarı elde etmek amacıyla etik ilkelerinden taviz vermez. &, 549 \\
\hline Yöneticim benim çlkarlarımı kendi çıkarlarının önüne koyar. &, 531 \\
\hline Açılanan Varyans & $\mathbf{5 8 , 7 9 3}$ \\
\hline Özdeğer & $\mathbf{3 , 5 2 8}$ \\
\hline Kaiser Mayer Ölçek Güvenilirliği &, $\mathbf{8 2 3}$ \\
\hline Bartlett's Küresellik Testi Ki-Kare & $\mathbf{1 , 4 4 8}$ \\
\hline P &, $\mathbf{0 0 0}$ \\
\hline Cronbach's Alfa & $\mathbf{8 1 6}$ \\
\hline
\end{tabular}


Tablo 2'de verilen örgütsel özdeşleşme ölçeğine ilişkin faktör analizi ve güvenirlilik bulgularına göre ölçek tek boyuttan oluşmakta ve ölçek maddeleri toplam varyansın \% 58,854'ünü açıklamaktadır (KMO=,784; $\mathrm{p}=0,000)$. Ölçeğin Cronbach's Alfa katsayısının , 849 olması, ölçeğin güvenilir olduğunu göstermektedir.

Tablo 2. Örgütsel Özdeşleşme Ölçeğine İlişkin Faktör Analizi ve Güvenilirlik Bulguları

\begin{tabular}{|l|l|}
\hline Maddeler & Faktör Yükü \\
\hline Çalıştı̆̆ım kurumdan bahsederken onlar değil biz diye konuşurum. &, 843 \\
\hline $\begin{array}{l}\text { Herhangi bir kişi çalıştığım kurumu övdüğünde, bunu kendime yapılmış bir övgü gibi } \\
\text { hissederim. }\end{array}$ &, 832 \\
\hline Başkalarının çalıştığım kurum hakkındaki düşünceleri benim için önemlidir. &, 824 \\
\hline Çalıştı̆̆ım kurumun başarısını kendi başarım gibi görürüm. &, 742 \\
\hline Herhangi bir kişi çalıştığım kurumu eleştirdiğinde üzüntü duyarım. &, 679 \\
\hline Medyada çalı̧tığım kurum ile ilgili kötü bir haber çısa üzüntü duyarım &, 663 \\
\hline Açıklanan Varyans & $\mathbf{5 8 , 8 5 4}$ \\
\hline Özdeğer & 3,531 \\
\hline Kaiser Mayer Ölçek Güvenilirliği &, 784 \\
\hline Bartlett's Küresellik Testi Ki-Kare & $\mathbf{1 , 1 0 3}$ \\
\hline P &, $\mathbf{0 0 0}$ \\
\hline Cronbach's Alfa &, 849 \\
\hline
\end{tabular}

İşgören performansı ölçeğine yönelik olarak yapılan açıklayıcı faktör analizi sonuçlarının gösterildiği Tablo 3'e bakıldığında, ölçekteki dört ifadenin tek bir boyut altında toplandığı ve bu ifadelerin toplam varyansın \% 60,094'ünü açıkladığı görülmektedir (KMO=,768; p=0,000).

Tablo 3. İşgören Performansı Ölçeğine İlişkin Faktör Analizi ve Güvenilirlik Bulguları

\begin{tabular}{|l|l|}
\hline Maddeler & Faktör Yükü \\
\hline Sunduğum hizmet kalitesinde standartlara fazlasıyla ulaştı̆̆ımdan eminim. &, 820 \\
\hline Görevlerimi tam zamanında tamamlarım. &, 806 \\
\hline İşimde gösterdiğim performansın kalite düzeyi yüksektir. &, 763 \\
\hline İş hedeflerime fazlasıly ulaşırım. &, 706 \\
\hline Açıklanan Varyans & $\mathbf{6 0 , 0 9 4}$ \\
\hline Özdeğer & $\mathbf{2 , 4 0 4}$ \\
\hline Kaiser Mayer Ölçek Güvenilirliği &, 768 \\
\hline Bartlett's Küresellik Testi Ki-Kare & $\mathbf{5 2 6 , 1 6}$ \\
\hline P &, $\mathbf{0 0 0}$ \\
\hline Cronbach's Alfa &, 771 \\
\hline
\end{tabular}

Tablo 4'te yer alan değişkenlere yönelik ortalama değerlere bakıldığında, katılımcıların performans $(x=3,24)$, örgütsel özdeşleşme $(x=3,18)$ ve algılanan hizmetkâr liderlik düzeyinin $(x=3,47)$ orta düzeyde olduğu tespit edilmiştir. Algılanan hizmetkâr liderlik ile çalışanların örgütsel özdeşleşme düzeyleri arasındaki ilişkinin yönünü ve düzeyini belirlemek amacıyla yapılan korelasyon analizi sonucuna göre, iki değişken arasında pozitif yönde $(\mathrm{r}:, 290)$ ve anlamlı bir ilişki $(\mathrm{p}<$.001) olduğu tespit edilmiştir. Aynı zamanda algılanan hizmetkâr liderlik ile çalışanların performans düzeyleri arasında pozitif yönde (r: ,414) ve anlamlı bir ilişki (p $<.001$ ) olduğu belirlenmiştir.

Tablo 4. Ölçeklere ilişkin Ortalama, Standart Sapma ve Korelasyon Değerleri

\begin{tabular}{lcccccc}
\hline Değişkenler & $\mathbf{n}$ & Ort. & Ss. & $\mathbf{1}$ & $\mathbf{2}$ & $\mathbf{3}$ \\
\hline 1.Performans & 392 & 3,24 &, 811 & 1 & & \\
2.Özdeşleşme & 392 & 3,18 &, 610 &, $546^{* *}$ & 1 & \\
3.Hizmetkâr Liderlik & 392 & 3,47 &, 595 &, $414^{* *}$ &, $290^{* *}$ & 1 \\
\hline
\end{tabular}

${ }^{* *} . \mathrm{p}<.001$ değerinde anlaml. 
Değişkenler arasındaki ilişkileri belirlemek amacıyla korelasyon analizi yapıldıktan sonra, hizmetkâr liderliğin çalışanların örgütsel özdeşleşme ve performans düzeylerini nasıl etkilediğini belirlemek amacıyla basit regresyon analizi yapılmış ve sonuçlar Tablo 5'te verilmiştir.

$\mathrm{R}^{2}$ değeri hizmetkâr liderliğin örgütsel özdeşleşmedeki değişimin \%,08'ini açıklayabildiği ve modelin anlamlı olduğunu göstermektedir ( $F=35,704 ; p<0,00)$. B değeri, hizmetkâr liderlik düzeyindeki bir birimlik artışın örgütsel özdeşleşme düzeyinde 0,29'luk bir artışa neden olduğunu göstermektedir. Bu sonuca göre araştırmadaki “H1: Algılanan hizmetkâr liderlik davranışı örgütsel özdeşleşmeyi pozitif yönde etkilemektedir" hipotezi kabul edilmiştir.

Tablo 5. Hizmetkâr Liderliğin Çalışanların Örgütsel Özdeşleşme ve Performansına Etkisine Yönelik Basit Doğrusal Regresyon Analizi

\begin{tabular}{|c|c|c|c|c|c|c|}
\hline \multirow{2}{*}{\multicolumn{2}{|c|}{ Model }} & \multicolumn{2}{|c|}{ Standartlaştırılmamış Katsayılar } & \multirow{2}{*}{$\begin{array}{c}\text { Standartlaştırılmış } \\
\text { Katsayılar } \\
\text { Beta } \\
\end{array}$} & \multirow[b]{2}{*}{$\mathbf{t}$} & \multirow{2}{*}{$\begin{array}{c}\text { Anlamlılık } \\
\text { Düzeyi }\end{array}$} \\
\hline & & B & Std. Hata & & & \\
\hline \multirow[t]{2}{*}{1} & Sabit & 2,858 & ,224 & & 12,747 & ,000 \\
\hline & $\begin{array}{l}\text { Hizmetkâr } \\
\text { Liderlik }\end{array}$ & ,297 & 050 &, 590 & 5,975 & , 000 \\
\hline
\end{tabular}

a.Bağımlı Değişken: Örgütsel Özdeşleşme $\left(R=, 290 ; R^{2}=0,084\right.$; Düzeltilmiş $R^{2}=0,082 ; F=35,704$; DurbinWatson $=1,613 ; \mathrm{p}=0,00$ )

\begin{tabular}{|c|c|c|c|c|c|c|}
\hline & & Standartlaşt & ş Katsayılar & $\begin{array}{l}\text { Standartlaştırılmış } \\
\text { Katsayılar }\end{array}$ & & Anlamlılık \\
\hline & & B & Std. Hata & Beta & $t$ & Düzeyi \\
\hline 1 & Sabit & 1,720 & ,284 & & 6,065 & ,000 \\
\hline & $\begin{array}{l}\text { Hizmetkâr } \\
\text { Liderlik }\end{array}$ & ,564 & ,063 & ,414 & 8,969 & ,000 \\
\hline
\end{tabular}

a.Bağımlı Değişken: İşgören Performansı $\left(R=, 414 ; R^{2}=0,171\right.$; Düzeltilmiş $R^{2}=0,169 ; F=80,441$; DurbinWatson $=1,968 ; \mathrm{p}=0,00$ )

Hizmetkâr liderliğin çalışan performansı üzerindeki etkisini belirlemek amacıyla yapılan regresyon analizi sonucuna göre hizmetkâr liderliğin çalışan performansındaki değişimin \%,17'sini açıkladığı ve bu modelin anlamlı olduğu belirlenmiştir. Aynı zamanda hizmetkâr liderlik davranışındaki bir birimlik artışın çalışanların performans düzeyi üzerinde $0,56^{\prime} l 1 \mathrm{k}$ bir artışa neden olduğunu göstermektedir. Bu verilere göre araştırmadaki "H2: Algılanan hizmetkâr liderlik davranışı çalışanların performansını pozitif yönde etkilemektedir" hipotezi kabul edilmiştir.

\section{Sonuç ve Değerlendirme}

Bu çalışmanın temel amacı yiyecek içecek işletmeleri çalışanlarının yöneticilerinde algıladıkları hizmetkâr liderlik davranışının çalışanların iş performansı ve sahip oldukları örgütsel özdeşleşme düzeyi üzerindeki etkisini belirlemektir. Bu amaç ile öncelikle kuramsal yapıya bağlı kalarak araştırmada üç tane hipotez geliştirilmiş ve bu hipotezlerin test edilmesi için İzmir ilinde faaliyet gösteren 392 birinci sınıf restoran çalışanı örnekleminde veriler toplanıp analiz edilmiştir. Araştırmada öncelikle çalışanların hizmetkâr liderlik algı, iş performansı ve örgütsel özdeşleşme düzeyleri belirlenmiştir.

Yapılan analizler neticesinde çalışanların yöneticilerinde algıladıkları hizmetkâr liderlik algı düzeylerinin orta seviyede çıktığ1 tespit edilmiştir. Bu sonuca göre restoran yöneticilerinin işletmenin hedeflerini gerçekleştirme sürecinde personellerin sorunlarıly ilgilenen, kariyer gelişimlerine, istek ve ihtiyaçlarına öncelik veren, etik ilkeler doğrultusunda hareket eden davranışlar sergiledikleri ifade edilebilir. Başka bir ifade ile restoran yöneticileri birer hizmetkâr lider gibi davranış göstermektedir. Baytok ve Ergen'de (2013) yapmış oldukları çalışmada hizmetkâr liderlik değerlerinin turizm işletmeleri ile önemli ölçüde örtüştüğünü ifade etmektedirler. Benzer şekilde Cinnioğlu ve Saçlı (2019) restoran işletmelerinin yapısının hizmetkâr liderlik davranışına uygun olduğunu belirtmişlerdir. Çevik ve Akoğlan Kozak da (2010) turizm sektörünün hizmet etme doğasından dolayı hizmetkârlı̆̆ın yönetsel anlamda önemli olduğunu vurgulamışlardır. 
Araştırmada elde edilen diğer bir sonuç ise çalışanların performanslarının orta düzeyde olduğudur. Başka bir ifade ile restoran çalışanlarının, işletmenin hedeflerini gerçekleştirmeye yönelik olarak çaba sarf ettikleri, görevlerini etkin, verimli ve kaliteli bir şekilde sürdükleri söylenebilir. Çalışanların örgütsel özdeşleşme düzeyini belirlemek amacıyla yapılan analizler neticesinde, bu düzeyin orta seviyede olduğu ortaya çıkmıştır. $\mathrm{Bu}$ sonuca göre restoran çalışanlarının işletmelerini benimsedikleri, kendilerini işletmeye ait hissettikleri ve işletmenin başarısı ya da başarısızlığı ile ilgili bir bağ kurdukları söylenebilir.

Araştırma sonuçlarına göre restoran yöneticilerinin hizmetkar liderlik davranışı sergilemesi çalışanlarının örgütsel özdeşleşme düzeyine olumlu katkılar sağlayabilecektir. Başka bir ifade ile hizmetkar liderlik özelliklerini gösterebilen yöneticilerin personellerinin örgütsel özdeşleşme düzeyi yüksek olabilecektir. Örgütsel özdeşleşme düzeyinin yüksek olması kuramsal çerçevede de belirtildiği gibi işletmeler açısından birçok önemli unsura katkı sağlayabilecektir. Elde edilen bu sonuç daha önce konuyla ilgili olarak yapılan birçok araştırmanın sonuçlarıyla (Zhang vd. 2012; Akbari vd. 2014; Ateş 2015; Thomas vd. 2015; Chughtai 2016; Narcıkara ve Zehir 2017; Çelik 2018; Nart vd. 2018; Tian 2018; Zorlu vd. 2019) benzerlik göstermektedir.

Araştırmada elde edilen diğer bir sonuçta hizmetkâr liderlik davranışının çalışanların iş performansı düzeyine pozitif yönde etki yapabileceğidir. Buna göre restoran yöneticilerinin hizmetkar liderlik davranışları göstermesi, çalışanları işletme amaçlarını gerçekleştirirken sergileyecekleri iş performansını arttırabilecektir. Akgöz (2017) insan gücü temeline dayalı olarak faaliyetlerini yürüten turizm işletmelerinde çalışanların performans düzeylerinin arttırılmasının birçok sorunu olduğunu belirtmektedir. Bu nedenle yöneticilerin hizmetkar liderlik davranışı sergilemesi bu sorunun çözüm yollarından bir olarak gösterilebilir. Araştırma kapsamında elde edilen bu sonuç daha önceki çalışmaların (Hussain ve Ali 2012; Chiniara ve Bentein 2016; Taşlıyan vd. 2016; Muhtasom vd. 2017; Wang vd. 2017) sonuçlarıyla da örtüşmektedir.

Yiyecek içecek sektörü yapısı gereği fiziksel ve zihinsel emeğin yoğun bir şekilde kullanıldığı, çalışma saatlerinin uzun ve esnek olduğu, misafirlerle yüz yüze iletişimin gerçekleştiği ve bu şartlara göre alınan ücretin az olduğu bir sektördür denilebilir. Bu şartlar altında çalışan kişilerin performans düzeylerinin yüksek olması ya da işletmeyle özdeşleşmeleri yöneticilerin göstereceği liderlik davranışlarına bağlı olabilmektedir. Bu nedenle yöneticilerin çalışanların istek ve ihtiyaçlarına önem vermesi, kariyer planlamalarına yardımcı olması, problemleriyle ilgilenmesi çalışanların performanslarına, işletmeye bağlılıklarına ya da işletmeyi sahiplenmelerine olumlu katkılar sağlayabilecektir.

$\mathrm{Bu}$ araştırma İzmir ilinde faaliyet gösteren birinci sınıf restoran işletmelerini kapsamaktadır. Konuyla ilgili gelecekte yapılacak çalışmalar farkı illerde ve farklı sektörlerde gerçekleştirilebilir. Bununla birlikte bu çalışmada hizmetkar liderlik davranışı bağımsız değişken olarak ele alınmıştır, ileriki çalışmalarda farklı modern liderlik davranışlarını incelenebilir.

\section{KAYNAKÇA}

Akbari, M., Kashani, S. H., Nikookar, H. ve Ghaemi, J. (2014). Servant Leadership And Organizational Identity: The Mediating Role Of Job Involvement, International Journal of Organizational Leadership. 3, 4155.

Akgöz, E. (2017). Turizm İşletmelerinde Çalışan Performansını Artırıcı Bir Unsur Olarak Kalite Çemberleri, Journal of Strategic Research in Social Science, 3 (3), 133-142.

Ali, A., Bin, L. Z., Piang, H. J. ve Zulfiqar, A. (2016). The Impact of Motivation on the Employee Performance and Job Satisfaction in IT Park (Software House) Sector of Peshawar, Pakistan, International Journal of Academic Research in Business and Social Sciences, Vol. 6, No. 9, 297-310.

Aliyev; Y. ve Işık M. (2014). Örgütsel Sosyalleşme Ve Örgütsel Özdeşleşme Arasındaki İlişki: Bir Araştırma, Sosyal Bilimler Enstitüsü Dergisi, Say1:37,/2, 131-149.

Amir, D. A. (2019). The Effect Of Servant Leadership On Organizational Citizenship Behavior: The Role Of Trust In Leader As A Mediation And Perceived Organizational Support As A Moderation, Journal of Leadership in Organizations Vol.1, No. 1, 1-16.

Ayan, A. (2015). Etik Liderlik Tarzının İş Performansı, İçsel Motivasyon ve Duyarsızlaşma Üzerine Etkisi: Kamu Kuruluşunda Bir Uygulama, Eskişehir Osmangazi Üniversitesi IİBF Dergisi, Aralık, 10(3), 117- 141. 
Baldonado, A. M. (2017). Servant Leadership: Learning From Servant Leaders of the Past and Their Impact to the Future, International Journal of Management Sciences and Business Research, Jan., Vol-6, Issue 1, 53-57.

Baytok, A. ve Ergen, F. D. (2013). Hizmetkâr Liderliğin Örgütsel Vatandaşlık Davranışına Etkisi: İstanbul ve Afyonkarahisar'daki Beş Yıldızlı Otel İşletmelerinde Bir Araştırma, İşletme Araştırmaları Dergisi, 5/4, 105-132.

Bhattacharya, C.B. ve Elsbach, K. D. (2002). Us Versus Them: The Roles of Organizational Identification and Disidentication in Social Marketing Initiatives, Journal of Public Policy \& Marketing, Vol. 21 (I), Spring, 26-36.

Brohi, N.A., Jantan, A.H., Qureshi, M.A., Bin Jaffar, A. R., Juha Bin, A. ve Hamid, K. B. A. (2018). The Impact Of Servant Leadership On Employees Attitudinal And Behavioural Outcomes, Cogent Business $\mathcal{E}$ Management, 5: 1542652, 1-17.

Chiniara, M. ve Bentein, K. (2016). Linking Servant Leadership to Individual Performance: Differentiating The Mediating Role Of Autonomy, Competence And Relatedness Need Satisfaction, The Leadership Quarterly, 27, 124-141.

Chughtai, A. A. (2016). Servant Leadership and Follower Outcomes: Mediating Effects of Organizational Identification and Psychological Safety, The Journal of Psychology, 150:7, 866-880.

Cinnioğlu, H., Atay, L. ve Diker, O. (2018). Yiyecek İçecek İşletmeleri Çalışanlarının Algıladıkları Hizmetkâr Liderlik Davranışının İşten Ayrılma Niyetine Etkisi, 19. Ulusal Turizm Kongresi, Türkiye: Afyonkarahisar, 99-111.

Cinnioğlu, H. ve Saçlı, Ç. (2019). Restoran Çalışanlarının Hizmetkâr Liderlik Algıları ile İşe Adanmışlık Düzeyleri Arasındaki İlişki, Journal Of Business Research-Tur, 11(3), 1769-1778.

Çakınberk, A., Derin, N. ve Demirel, E. T. (2011). Örgütsel Özdeşleşmenin Örgütsel Bağlılıkla Biçimlenmesi: Malatya ve Tunceli Özel Eğitim Kurumları Örneği, İsletme Araştırmaları Dergisi, 3/1, 89-121.

Çelik, N. (2018). The Effect Of Accommodation Enterprises Workers' Perception Of Servant Leadership On Organizational Identification: The Case Of Konya, Mehmet Akif Ersoy Üniversitesi İktisadi ve İdari Bilimler Fakültesi Dergisi, Cilt: 5, Sayı: 3, 765-782.

Çevik, S. ve Akoğlan Kozak, M. (2010). Değişim Yönetiminde Dönüşümcü Liderlik ve Hizmetkâr Liderlik, 11. Ulusal Turizm Kongresi, 2-5 Aralık, Kuşadası, 80-87.

Çöl, G. (2008). Algılanan Güçlendirmenin İşgören Performansı Üzerine Etkileri, Doğuş Üniversitesi Dergisi, 9 (1), 35-46.

Dahkoul, Z. M. (2018). The Determinants of Employee Performance in Jordanian Organizations, Journal of Economics, Finance and Accounting (JEFA), V.5, Iss.1, 11-17.

Eker, D. (2015). Öğretim Elemanı Örgütsel Özdeşleşme Ölçeği Geçerlik Ve Güvenirlik Çalışması, Eğitim ve Öğretim Araştırmaları Dergisi, Cilt:4, Sayı:4, Makale No: 13, 118-124.

Eva, N., Robin, M., Sendjaya, S., Dierendonck, D.V. ve Liden, R. C. (2019). Servant Leadership: A Systematic Review And Call For Future Research, The Leadership Quarterly, 30, 111-132

Fettahlığlu, Ö. O. ve Koca, N. (2015). Örgütsel Özdeşleşme Ve Örgütsel Vatandaşlık İlişkisinde Örgütsel Desteğin Düzenleyici Etkisi, Sosyal Bilimler Dergisi, Yıl: 2, Sayı: 4, Eylül, 1-10.

Gandolfi; F. ve Seth S. (2018). Leadership, Leadership Styles, and Servant Leadership, Journal of Management Research, Vol. 18, No. 4, Oct.-Dec., 261-269.

Greenleaf, R. K. (1977). Servant Leadership: A Journey Into The Nature of Legitimate Power and Greatness, Paulist Press, New York.

Hamzagic, E. (2018). The Importance of the Organizational Identification in Forming Organizational Perception, International Review, No 1-2, 1-11. 
Hussain, T. ve Ali, W. (2012). Effects Of Servant Leadership On Followers' Job Performance, Science, Technology and Development, 31 (4): 359-368.

Jones, C. ve Volpe, E. H. (2010). Organizational Identification: Extending Our Understanding Of Social Identities Through Social Networks, Journal of Organizational Behavior, 32: 413-434.

Kerse, G. ve Karabey C. N. (2017). Algılanan Örgütsel Desteğin Örgütsel Özdeşleşmeye Etkisi: Örgütsel Sinizmin Aracı Rolü, MANAS Sosyal Araştırmalar Dergisi, Cilt 6, Sayı 4, 375-398.

Kılıç, K.C. ve Aydın, Y. (2016). Hizmetkâr Liderlik Ölçeğinin Türkçe Uyarlaması: Güvenirlik ve Geçerlik Çalışması, KMÜ Sosyal ve Ekonomik Araştırmalar Dergisi, 18 (30): 106-113.

Lee, A., Lyubovnikova, J., Tian, Amy W., Knight, C. (2019). Servant Leadership: A Meta-Analytic Examination Of Incremental Contribution, Moderation, And Mediation, Journal of Occupational and Organizational Psychology, https://doi.org/10.1111/joop.12265.

Liden, R. C., Wayne, S., Zhao, H. ve Henderson, D. (2008). Servant Leadership: Development of A Multidimensional Measure and Multi-Level Assessment, The Leadership Quarterly, 19, 161-177.

Liden, R. C., Sandy J. W., Meuser, J.D., Hu, J., Wu, J. ve Liao, C. (2015). Servant Leadership: Validation of A Short Form of The SL-28, Leadership Quarterly, 26 (2): 254-269.

Lipponen, J., Bardi, A. ve Haapamaki, J. (2008). The Interaction Between Values And Organizational Identification in Predicting Suggestion-Making At Work, Journal of Occupational and Organizational Psychology, 81, 241-248.

Mael, F. ve Ashforth, B. E. (1992). Alumni And Their Alma Mater: A Partial Test Of The Reformulated Model Of Organizational Identification, Journal of Organizational Behavior, Vol 13, 2, 103-123.

Muhtasom, A., Mus , H. A. R., Bijang, J. ve Latief, B. (2017). Influence of Servant Leadership, Organizational Citizenship Bahaviour on Organizational Culture and Employee Performance at Star Hotel in Makassar, International Journal of Education and Research Vol. 5 No. 10, 71-88.

Narcıkara, E. B. ve Zehir, C. (2017). Effect Of Gratitude in The Relationship Between Servant Leadership And Organizational Identification, ISMC 2017 13th International Strategic Management Conference, 372384.

Patterson, K. (2003). Servant Leadership: A Theoretical Model, Servant Leadership Research Roundtable. School of Leadership Studies Regent University, 1-10.

Nart, S., Yaprak, B., Yıldırım, Y. T. ve Sarıhan, Ahmet Y. (2018). The Relationship Of Diversity Management And Servant Leadership With Organizational Identification And Creativity in Multinational Enterprises, Finans Politik \& Ekonomik Yorumlar, Cilt: 55, Sayı: 637, 31-47.

Shoukat, S., Khan, M.I. ve Waqas, A. (2019). The Effects of Servant Leadership on Organizational Citizenship Behaviour: Moderation of Proactive Personality, International Journal of Scientific and Research Publications, Volume 9, Issue 4, April, 67-74.

Singfiel, J. (2018). When Servant Leaders Appear Laissez-Faire: The Effect Of Social Identity Prototypes On Christian Leaders, The Journal Of Applied Christian Leadership, Vol 12, No 1, 64-77.

Taşlıyan, M., Hırlak, B. ve Harbalığlu, M. (2016). The Effect Of Servant Leadership On Organizational Citizenship Behaviour And Performance Of Employee: A Research On Hotel Managements In Gaziantep, The Journal of International Social Research, Volume: 9 Issue: 44, 1232-1240.

Tekin, E. (2018). Lider-Üye Etkileşiminin Çalışan Performansı Üzerindeki Etkisinde Örgütsel Vatandaşlık Davranışının Aracı Rolü, Karadeniz Teknik Üniversitesi Sosyal Bilimler Enstitüsü Sosyal Bilimler Dergisi, Y1l: 8 Sayı: 16, Aralık, 343-363.

Tekingündüz, S., Kurtuldu, A. ve Eğilmez, Ç. (2016). Sosyal Destek, İşe Yabanclaşma ve İş Stresinin İşgören Performansı Üzerindeki Etkisinin İncelenmesi, International Journal of Human Sciences, 13(1), 683-694. 
H. Cinnioğlu 11/4 (2019) 2902-2911

Thomas, C. H., Craig, J. B., Dibrell, C. ve Marshall, D. R. (2015). Servant Leadership and Organizational Identification: A Family Firm Perspective, Academy of Management Proceedings, Vol. 2015, No. 1.

Tian, Q., Hu, Y. ve Cheng, K. (2018). Servant Leadership and Voice Behavior: Organizational Identification as a Mediator, International Conference on Information Technology and Management Engineering, Advances in Intelligent Systems Research, Volume 148, 126-128.

Tokgöz, E. ve Seymen, O. A. (2013). Örgütsel Güven, Örgütsel Özdeşleşme Ve Örgütsel Vatandaşlık Davranış1 Arasındaki İlişki: Bir Devlet Hastanesinde Araştırma, Öneri. C.10.S.39, Ocak, 61-76.

Tsuchiya, Y. (2017). A Critical Review Of Organizational Identifıcation: Introducing Identity Work To Examine Dynamic Process, Journal of Organizational Culture, Communications and Conflict, Volume 21, Issue 2, 110.

Turunç, Ö. ve Çelik, M. (2010). Örgütsel Özdeşleşme Ve Kontrol Algılamalarının, Çalışanların İşten Ayrılma Niyeti Ve İş Performansına Etkileri, Atatürk Üniversitesi İktisadi ve İdari Bilimler Dergisi, Cilt: 24, Sayı: 3, 163-181.

Uygur, A. (2007). Örgütsel Bağlılık İle İşgören Performansı İlişkisini İncelemeye Yönelik Bir Alan Araştırması, Ticaret ve Turizm Egitim Fakültesi Dergisi, Yıl: 2007 Sayı: 1, 71-85.

Wang, Z., Xu, H. ve Liu, Y. (2017). Servant Leadership As A Driver Of Employee Service Performance: Test Of A Trickle-Down Model And Its Boundary Conditions, Human Relations, 0, 0, 1-25.

Web 1: https://izmir.ktb.gov.tr/TR-77197/belgeli-yeme-icme-tesis-listesi.html (Erişim Tarihi 12.07.2019).

Winston, B. (2003). Extending Patterson's Servant Leadership Model: Explaining How Leaders and Followers Interact In A Circular Model. Servant Leadership Research Roundtable August, School of Leadership Studies, Regent University, 1-9.

Wong, P. T. P. ve Page, D. (2003). Servant Leadership: An Opponent-Process Model and The Revised Servant Leadership Profile, Servant Leadership Research Roundtable, August, 1-13.

Yıldırım, K..E. (2019). Hizmetkâr Liderlik ve Çalışan Davranışlarındaki Rolü: Kırgızistan'da Bir Alan Araştırması, İşletme Araştırmaları Dergisi, 11(3), 2242-2256.

Yılmaz, H. ve Karahan, A. (2010). Liderlik Davranışı, Örgütsel Yaratıcılık ve İşgören Performansı Arasındaki İlişkilerin İncelenmesi: Uşak'ta Bir Araştırma, Yönetim Ve Ekonomi, Cilt:17, Sayı:2, 145-158.

Zhang, H., Kwan, Ho K., Everett, A. M. ve Jian, Z. (2012). Servant Leadership, Organizational Identification, And Work-To-Family Enrichment: The Moderating Role Of Work Climate For Sharing Family Concerns, Human Resource Management, September-October, Vol. 51, No. 5. 747-768.

Zorlu, Ö., Avan, A. ve Baytok, A. (2019). The Effect of Servant Leadership on Psychological Empowerment and Organizational Identification, Journal of Business Research-Turk, 11 (1), 293-309.

Ural, A. ve Kılıç, İ. (2013). Bilimsel Araştırma Süreci ve SPSS İle Veri Analizi. Detay Yayıncılık, 4 Baskı, Ankara. 